\title{
22. TWO "EVENTS" RECORDED IN THE BRUNHES CHRON AT HOLE 650A (ODP LEG 107, TYRRHENIAN SEA): GEOMAGNETIC PHENOMENA? ${ }^{1}$
}

\author{
J.E.T. Channell ${ }^{2}$ and M. Torii ${ }^{3}$
}

\begin{abstract}
The Brunhes Chron at Hole 650A is represented by about $415 \mathrm{~m}$ of volcaniclastic turbidites. Two intervals where the remanent magnetization has negative inclination are recognized in the Brunhes. Orthogonal projections of thermal demagnetization data from these intervals indicate that a well-defined single magnetization component can be resolved. "Event A" is recorded over a stratigraphic thickness of about $9 \mathrm{~m}$, and "Event B" over a stratigraphic thickness of about $1.5 \mathrm{~m}$. The record of "Event A" spans more than one core. Biostratigraphic and stable isotope data help to constrain the age of these "events." "Event A" is inferred to occur in oxygen isotopic Stage 2 (12-24 ka), and "Event B" in isotopic Stage 5 (73-130 ka).

In these particular intervals, the color and compositional banding indicates that the cores are relatively undeformed. The presence of a steep downward magnetic overprint at this hole indicates that the negative inclinations cannot be explained by inadvertent flipping of cores or core sections. Negative inclinations of magnetic remanence associated with "Event A" and "Event B" are recorded entirely within fine grained calcareous muds that may constitute the upper parts of distal turbidite flows. Due to failure of the "multishot" core orientation device, the remanence declination values are relative.
\end{abstract}

\section{INTRODUCTION}

The subject of geomagnetic "events" within the Brunhes Chron is fraught with controversy. Even the higher quality records of supposed geomagnetic "events" remain controversial, in part because these phenomena are not well correlated to one another. This lack of clear correlation may be due to the local or regional manifestation of the "events," rather than inadequate age estimates. Among the proposed Brunhes "events" there are concentrations of recordings in the $20-50 \mathrm{ka}$ and $100-150 \mathrm{ka}$ intervals. The former group includes those from Mono Lake (Liddicoat and Coe, 1979), Summer Lake (Negrini et al., 1984), Lake Mungo (Barbetti and McElhinny, 1972), Laschamp (Bonhommet and Zahringer, 1969), and Lake Biwa (Yaskawa et al., 1973). The latter group includes the Blake Event which has been recorded in the Atlantic (Smith and Foster, 1969) and Caribbean (Denham, 1976) and has been correlated to paleomagnetic records from Italy (Creer et al., 1980), Japan (Kawai et al., 1972; Nakajima and Miura, 1982), Poland, and the Tyrrhenian Sea (Tucholke et al., 1987).

Hole $650 \mathrm{~A}$ provides an exceptionally thick record of the Brunhes Chron $(415 \mathrm{~m})$, indicating an average sedimentation rate of $57 \mathrm{~cm} / \mathrm{k}$.y. The APC (advanced piston corer) was used down to $120 \mathrm{~m}$ below seafloor (mbsf), and the XCB (extended core barrel) technique to $634 \mathrm{mbsf}$. The lithology in the Brunhes Chronozone comprises calcareous muds, alternating with volcaniclastic silts and sands. Grain size distributions indicate that the entire sequence is probably turbiditic, with the calcareous muds constituting the upper parts of individual flows (Hieke, pers. comm., 1987).

\section{MAGNETIC PROPERTIES}

The shipboard cryogenic magnetometer was not used at Site 650 for two reasons. First, the magnetometer electronics were

\footnotetext{
${ }^{1}$ Kastens, K. A., Mascle, J., et al., 1990. Proc. ODP, Sci. Results, 107: College Station, TX (Ocean Drilling Program).

2 Department of Geology, University of Florida, Gainesville, FL 32611.

3 Department of Geology and Mineralogy, Kyoto University, Kyoto 606, Japan.
}

being modified during the previous Leg and failed to reach the ship until midway through the cruise, by which time the drilling of Site 650 had been completed. Second, the maximum alternating field available in conjunction with the shipboard cryogenic magnetometer $(8 \mathrm{mT})$ was generally insufficient to demagnetize a steeply inclined secondary magnetic overprint. All cores recovered at Site 650 were subsampled using $7 \mathrm{~cm}^{3}$ plastic cubes. On board ship, most samples were partially demagnetized in alternating fields up to a peak field of $20 \mathrm{mT}$. Subsequent thermal demagnetization on shore improved the quality of the magnetostratigraphy. All samples were progressively thermally demagnetized, the high blocking temperature component computed, and the polarity determination based on the inclination of this component (see Channell, Torii and Hawthorne, this volume). The inclination record can be interpreted in terms of a number of polarity zones with the Olduvai subchron at the base of the Hole (Fig. 1). Two "events" characterized by negative inclinations within the Brunhes Chronozone, labeled "Event A" and "Event B" in Figure 1, are the subject of this paper.

Unfortunately, the photographic "multishot" core orientation device was not functioning adequately during the drilling of Hole $650 \mathrm{~A}$. For Cores $2 \mathrm{H}$ to $7 \mathrm{H}$ and Core $10 \mathrm{H}$, very variable azimuthal readings were recorded from one photographic frame to the next. The variable readings may indicate rotation of the core barrel during entry. The orientation system failed completely for Cores $8 \mathrm{H}, 9 \mathrm{H}$, and $11 \mathrm{H}$, as well as for Core $12 \mathrm{H}$, which was the final core recovered using the APC. As a result, only relative declination data are available, and the evidence for the "events" rests largely with the inclination data.

For the top $100 \mathrm{~m}$ of core recovered at Hole $650 \mathrm{~A}$, the inclinations of the natural remanent magnetization (NRM) are steep and positive with the exception of an interval of lower inclinations between 10 and 20 mbsf (Fig. 2). Alternating field demagnetization to maximum peak fields of $20 \mathrm{mT}$ progressively shallows the inclinations. In the $10-20 \mathrm{mbsf}$ interval, and close to 100 mbsf, values become negative (Fig. 2). Subsequent thermal demagnetization steepens the inclinations in the two intervals with negative values (Fig. 2). The fact that the inclinations of the NRM are generally positive and steep throughout the core, and that the inclinations become generally shallower and, in the two "anomalous" intervals, negative after partial demagnetiza- 


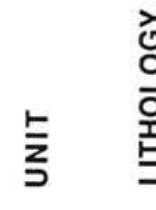

$$
\text { 总 }
$$
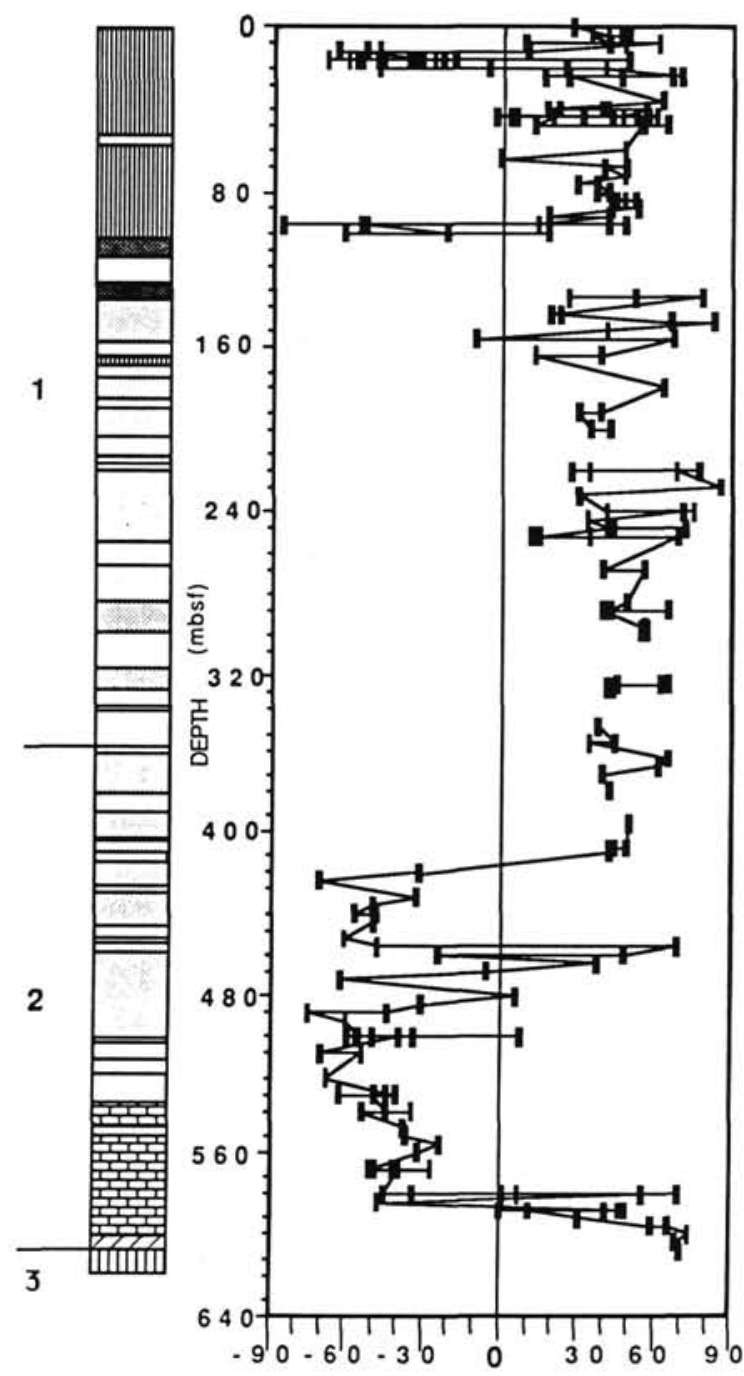

INCLINATION
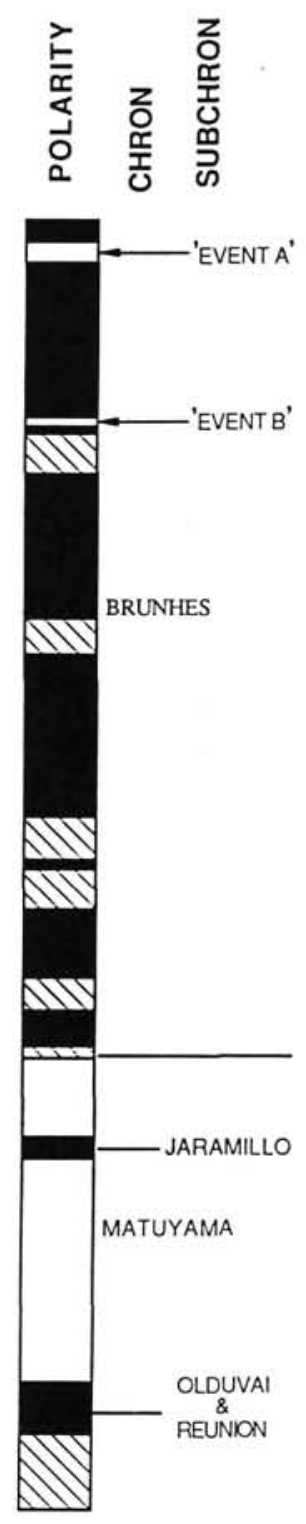

\section{(2)}

Figure 1. Lithologic log, inclination of the characteristic magnetization component, and polarity interpretation for Hole 650A (from Channell, Torii, and Hawthorne, this volume). tion, suggests the presence of a steep positively inclined overprint throughout this part of the core. This, in turn, precludes the possibility that intervals of negative inclination are due to inadvertent flipping of cores or core sections.

After alternating field demagnetization to peak fields of 20 $\mathrm{mT}$, each sample from Hole $650 \mathrm{~A}$ was subjected to progressive thermal demagnetization. Orthogonal projections of thermal demagnetization data indicate that the magnetization is dominated by a single, high blocking temperature component which can be resolved at demagnetization temperatures above a few hundred degrees Celsius. The nature of the magnetization in the interval between 10 and 20 mbsf is critical to this discussion, and orthogonal projections from this interval are presented in Figure $3(\mathrm{~A}-\mathrm{C})$. For each plot, the straight line trajectory of the vector end-points toward the origin tends to indicate that a sin- gle magnetization component can be resolved. This same component cannot always be resolved by alternating field demagnetization (Fig. 4). For example, alternating field treatment of Samples $650 \mathrm{~A}-3 \mathrm{H}-4,86-88 \mathrm{~cm}$, and $650 \mathrm{~A}-3 \mathrm{H}-5,96-98 \mathrm{~cm}$, indicates a magnetization dominated by a component with positive inclination (Fig. 4). Subsequent thermal demagnetization of these two samples gives clearly defined components with negative inclination (Fig. 3C). Note that although the "Event A" interval of negative inclinations is largely restricted to Core $3 \mathrm{H}$, the uppermost sample with negative inclination is in Core $2 \mathrm{H}$, Section 7 (Fig. 3A). The lowcrmost sample with negative inclination is at $650 \mathrm{~A}-3 \mathrm{H}-5,96-98 \mathrm{~cm}$ (Fig. $3 \mathrm{C}$ ), and the inclinations become positive at $650 \mathrm{~A}-3 \mathrm{H}-6,29-31 \mathrm{~cm}$ (Fig. 3C). The interval of negative inclinations is therefore not restricted to Core $3 \mathrm{H}$, and the base of the interval occurs within Core $3 \mathrm{H}$. This distri- 


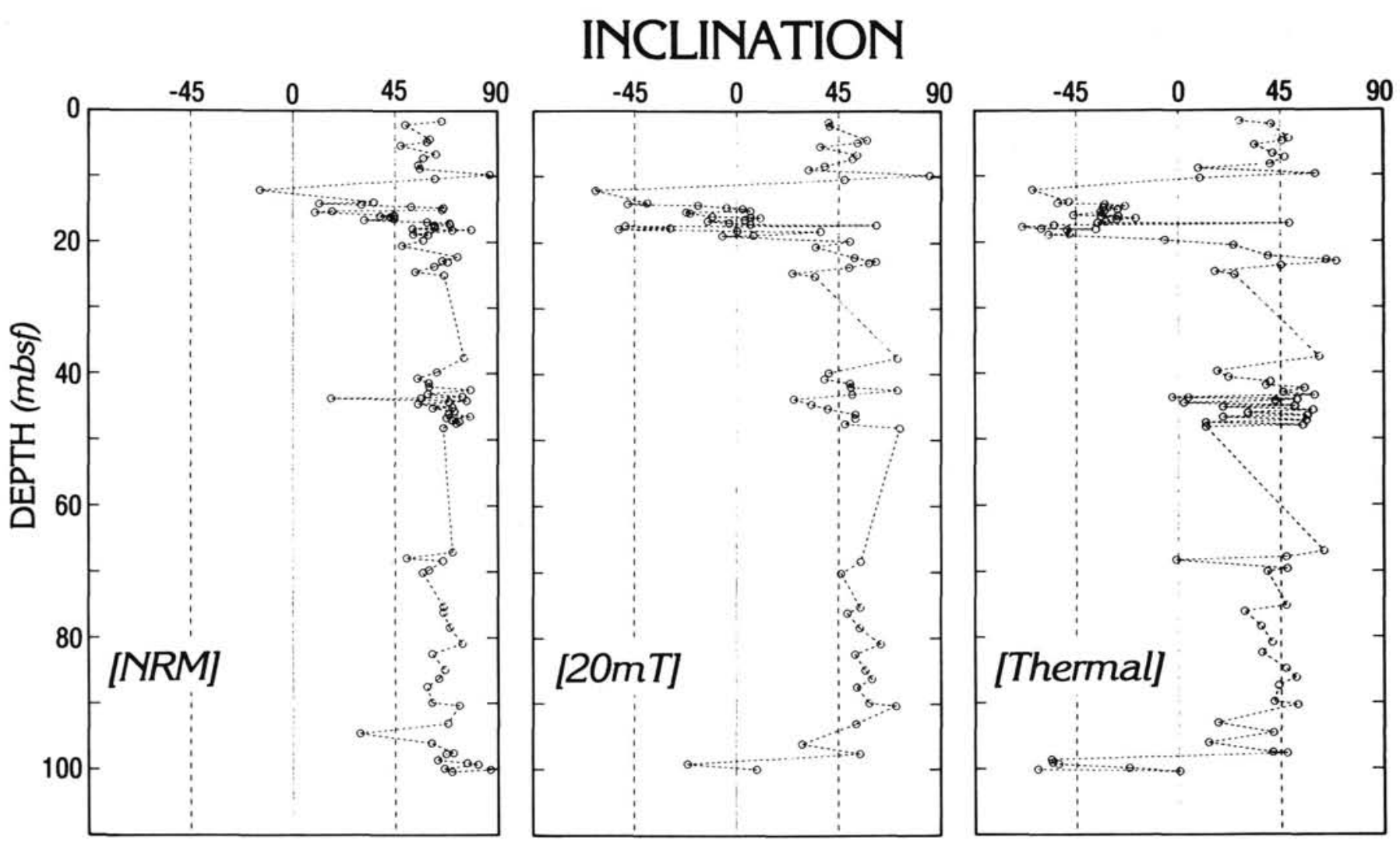

Figure 2. Inclinations of the natural remanent magnetization (NRM), inclinations of remanence after demagnetization at peak fields of $20 \mathrm{mT}$, and inclinations of the high blocking temperature component resolved by thermal demagnetization, for the upper 100 mbsf at Hole $650 \mathrm{~A}$.

bution provides additional evidence that the negative inclinations are not due to inadvertent flipping of cores or core sections.

"Event B" and its lower and upper bounds lie entirely within Core $11 \mathrm{H}$ at about 100 mbsf (Fig. 2). Orthogonal projections of thermal demagnetization data (Fig. 5) indicate that a magnetization component with negative inclination is isolated in this interval, although the components are not as well defined as those from "Event A."

The turbiditic nature of the lithology at Hole 650A necessitates a careful comparison of the lithologic and magnetic characteristics of the sediments. The shipboard magnetic susceptibility record (Fig. 6) appears to reflect grain-size variations in the turbiditic sediments. This is demonstrated by detailed comparisons of lithologic logs with the susceptibility record (Figs. 7 and 8), which indicate that high values of susceptibility correlate with the coarser grained basal parts of turbidite flows. Grain size studies indicate that the fine grained calcareous muds, interbedded with the coarser grained silts and sands, are usually the fine grained upper parts of turbidite flows (Hieke, pers. comm., 1987). The inclination anomalies are recorded in the apparently undeformed, fine grained calcareous muds (Figs. 7 and 8); the coarser grained sediments were generally avoided during shipboard sampling.

The inclination and relative declination values plotted in Figures 7 and 8 were computed from orthogonal projections using a least squares technique similar to that advocated by Kirschvink (1980). Only those components with maximum angular deviations less than $10^{\circ}$ are plotted in these two figures. The inclination values are generally better grouped than the within-core declination values. This may reflect rotation of the core barrel during penetration, which is also implied by the highly variable readings obtained from the "multishot" orientation device.

\section{AGE CONSTRAINTS}

Biostratigraphic, magnetostratigraphic, and isotopic age constraints are available for Hole 650A (Fig. 9). Clearly, the polarity stratigraphy does not provide tight constraints within the Brunhes Chronozone because, for this lithology, we have no reason to assume constant sedimentation rates. The oxygen isotope stratigraphy for Globigerina bulloides is defined by relatively few samples at this hole (Vergnaud Grazzini et al., this volume), however some stages have been recognized (column A in Fig. 9). The recognition of "cold" and "warm" planktonic foraminiferal assemblages provides a means of independently checking the isotope chronology. For Hole $650 \mathrm{~A}$, the planktonic foraminiferal record has been interpreted in terms of isotopic stages (Glaçon, unpubl. data, reported in Channell, Rio, Sprovieri, and Glaçon, this volume) (column B in Fig. 9). The process has been aided by correlation of these assemblages to the more detailed isotopic and biostratigraphic data from Hole 653A (Vergnaud Grazzini et al., this volume). There is a general consistency between the interpretation of the isotopic curve, and the biostratigraphically-based "isotopic" chronology, with one notable exception. Stage 6 from the isotopic record appears to correlate with Stage 5 from the biostratigraphic record (Fig. 9). Glaçon (unpubl. data) noted the presence of reworked "cold" assemblages from Stage 6 in this interval, but considered that the "in situ" assemblage correlates to Stage 5. Reworking in a turbiditic environment is probably the explanation for the inconsistency. Other potential chronostratigraphic tools within the Brunhes Chron at Hole 650A, such as tephrochronology and sapropel correlation have not yet provided additional age constraints.

Glaçon (unpubl. data, reported in Channell, Rio, Sprovieri, and Glaçon, this volume) place Termination I (Broecker and van 


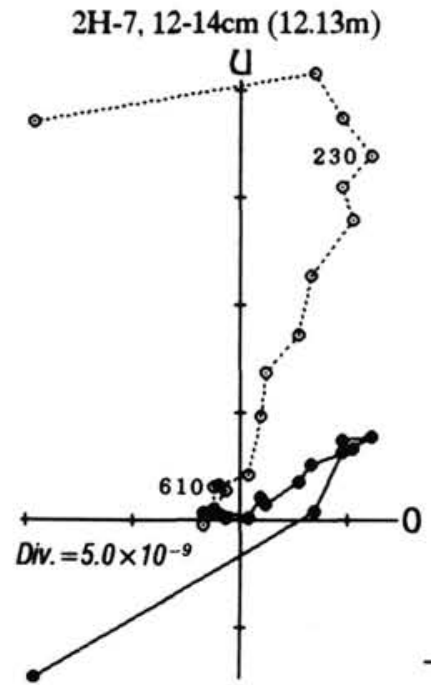

$3 \mathrm{H}-2,10-12 \mathrm{~cm}(14.31 \mathrm{~m})$

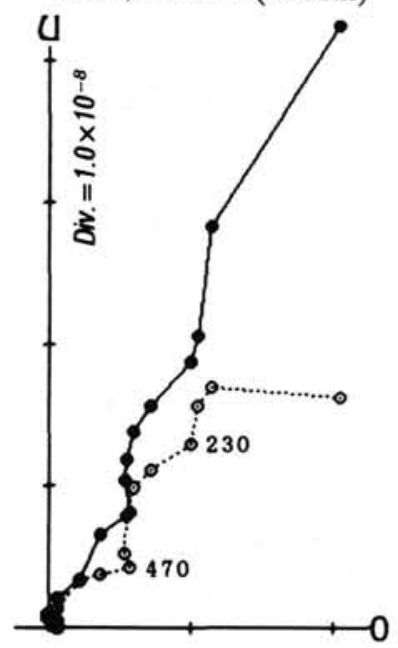

$3 \mathrm{H}-2,56-58 \mathrm{~cm}(14.77 \mathrm{~m})$

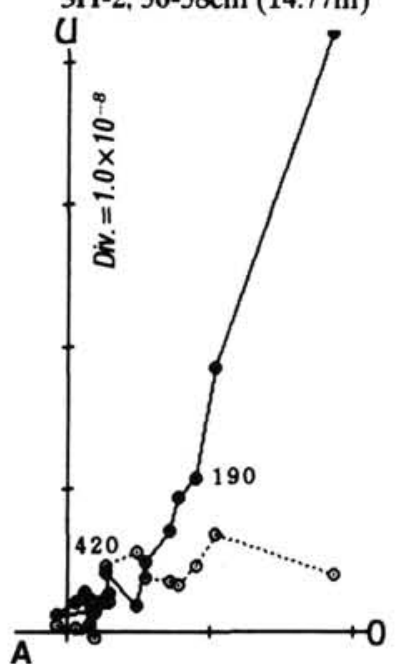

$3 \mathrm{H}-1,123-125 \mathrm{~cm}(13.94 \mathrm{~m})$

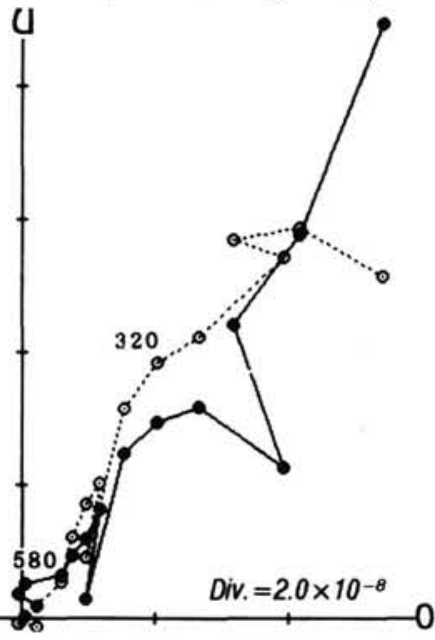

$3 \mathrm{H}-2,37-39 \mathrm{~cm}(14.58 \mathrm{~m})$

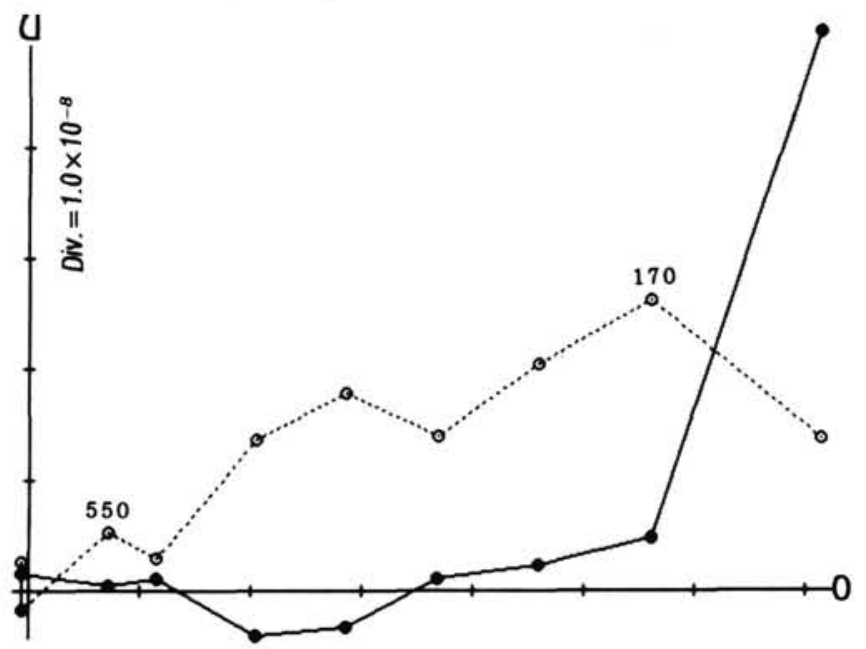

$3 \mathrm{H}-2,87-89 \mathrm{~cm}(15.08 \mathrm{~m})$

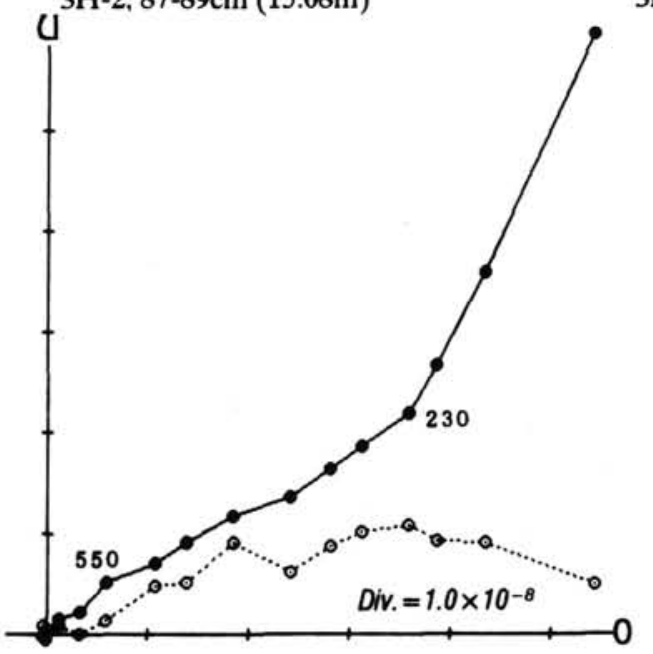

$3 \mathrm{H}-2,110-112 \mathrm{~cm}(15.31 \mathrm{~m})$

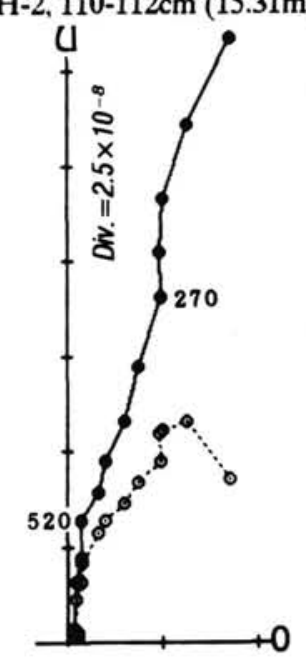

Figure 3. Orthogonal projections of thermal demagnetization data for samples recording "Event $\mathrm{A}$ " at Hole $650 \mathrm{~A}$. A. 12.13-15.31 mbsf. B. $15.45-17.31$ mbsf. C. $17.43-20.50 \mathrm{mbsf}$. Note that the uppermost sample recording a negative inclination is from Core $2 \mathrm{H}$, and the remainder of the negative inclinations are from Core $3 \mathrm{H}$. Open and solid symbols (connected by dotted and continuous lines) indicate projection on the vertical and horizontal planes, respectively. For the vertical projection, " $U$ " indicates the upward direction. For the horizontal projection, " 0 " indicates the direction perpendicular to, and toward, the split surface of the working-half of the core. "Div." refers to the total moment $\left(\mathrm{Am}^{2}\right)$ corresponding to each division indicated by the tick marks. The demagnetization temperatures in degrees Celsius are indicated for some of the points. 
TWO EVENTS IN THE BRUNHES CHRON AT HOLE 650A: GEOMAGNETIC PHENOMENA?

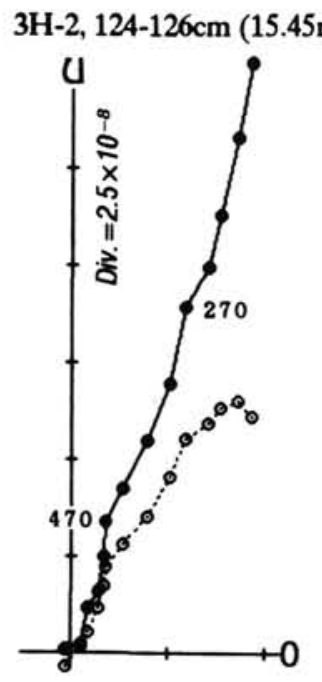

$3 \mathrm{H}-3,45-47 \mathrm{~cm}(16.16 \mathrm{~m})$

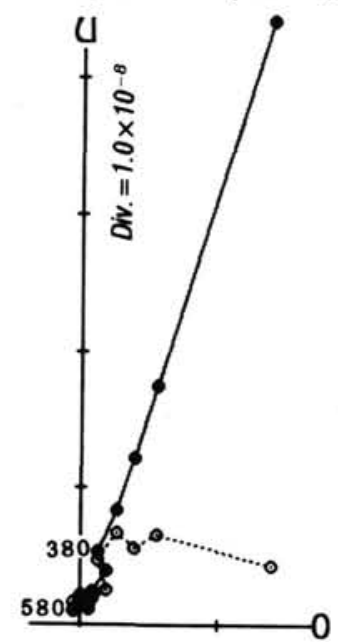

$3 \mathrm{H}-3,123-125 \mathrm{~cm}(16.94 \mathrm{~m})$

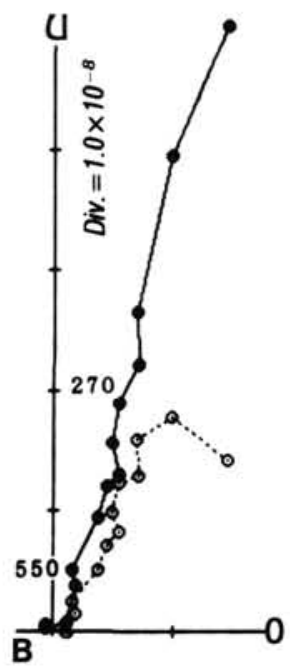

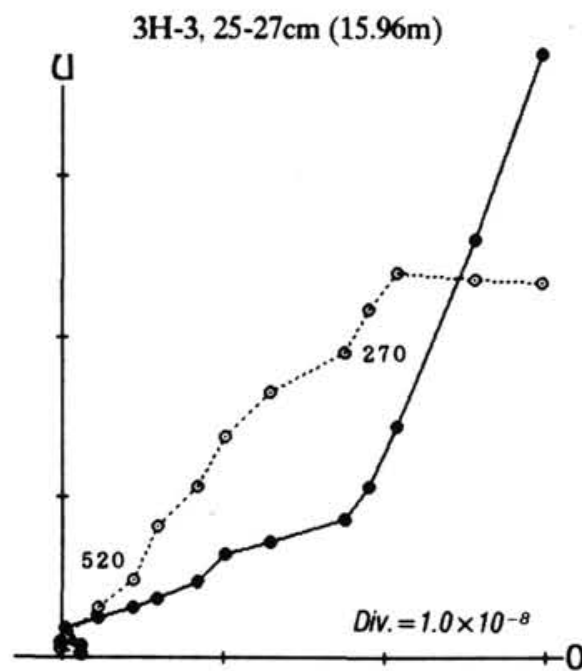

$3 \mathrm{H}-3,72-74 \mathrm{~cm}(16.43 \mathrm{~m})$

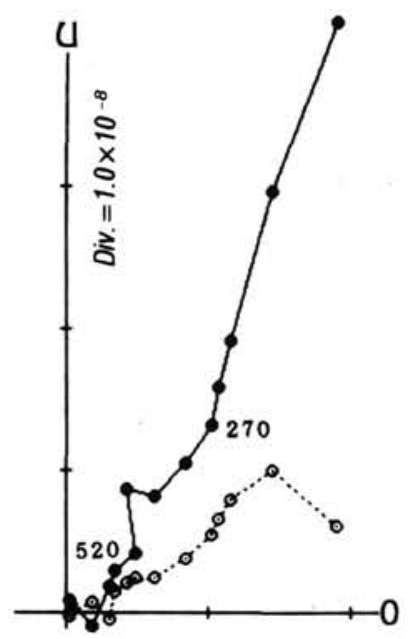

$3 \mathrm{H}-3.140-142 \mathrm{~cm}(17.11 \mathrm{~m})$

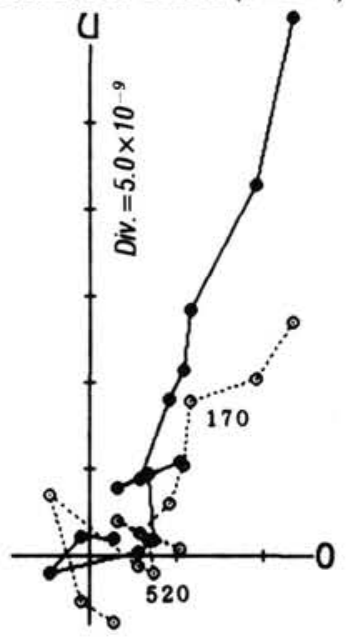

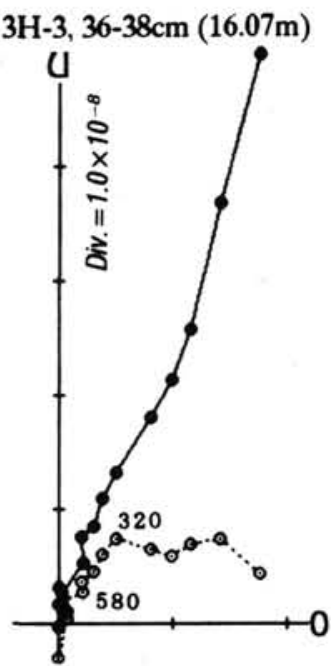

$3 \mathrm{H}-3,97-99 \mathrm{~cm}(16.68 \mathrm{~m})$

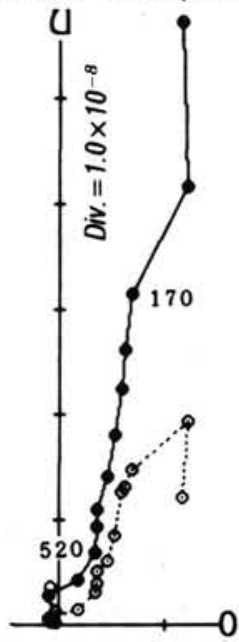

$3 \mathrm{H}-4,10-12 \mathrm{~cm}(17.31 \mathrm{~m})$

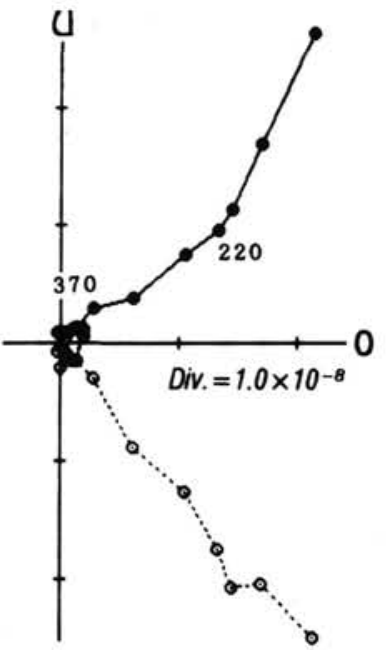

Figure 3 (continued). 
$3 \mathrm{H}-4,22-24 \mathrm{~cm}(17.43 \mathrm{~m})$

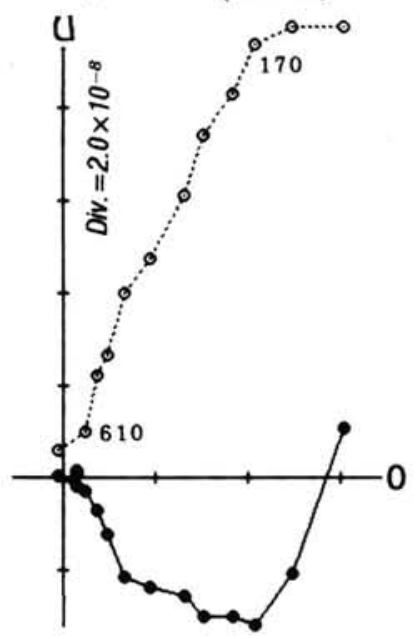

$3 \mathrm{H}-4.86-88 \mathrm{~cm}(18.07 \mathrm{~m})$

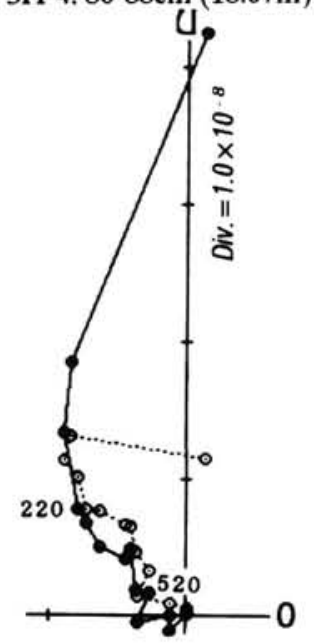

$3 \mathrm{H}-4,49-51 \mathrm{~cm}(17.70 \mathrm{~m})$

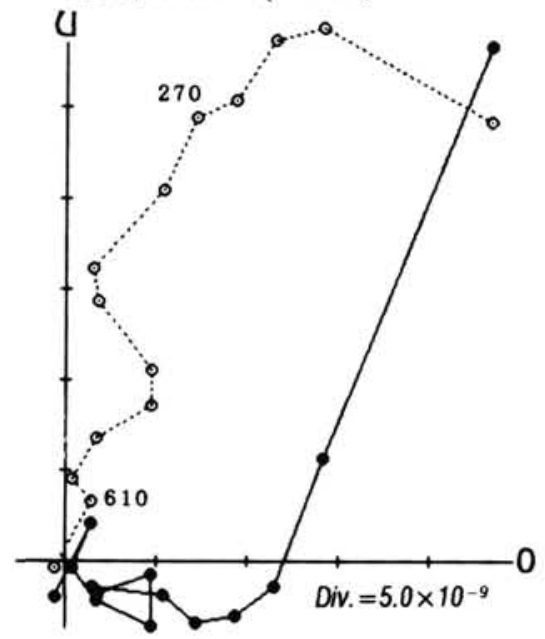

$3 \mathrm{H}-4.75-77 \mathrm{~cm}(17.96 \mathrm{~m})$

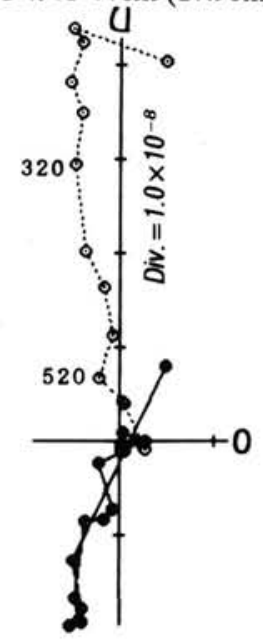

$3 \mathrm{H}-4.97-99 \mathrm{~cm}(18.18 \mathrm{~m}) \quad 3 \mathrm{H}-5.4-6 \mathrm{~cm}(18.75 \mathrm{~m})$
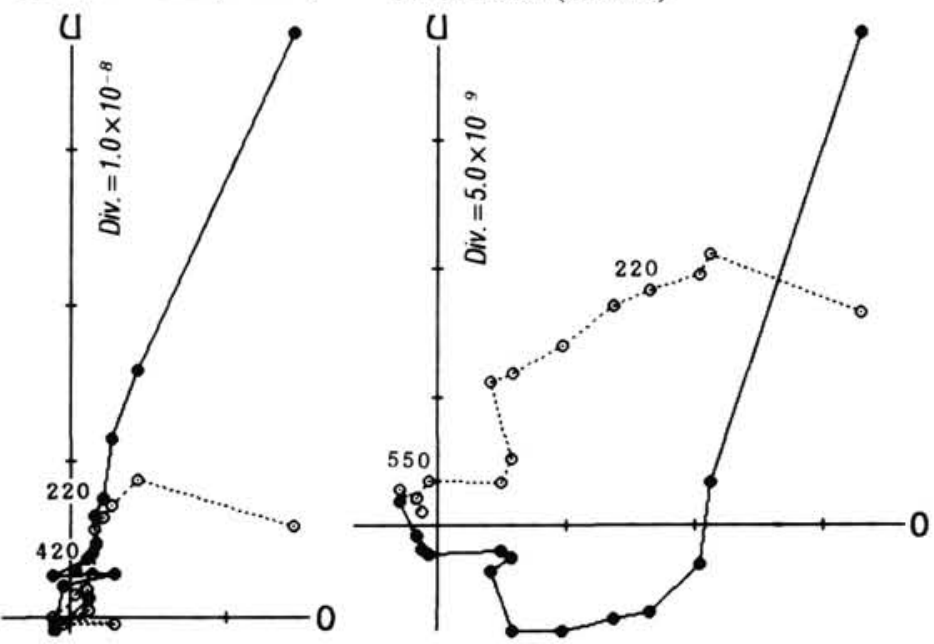

$3 \mathrm{H}-5,17-19 \mathrm{~cm}(18.88 \mathrm{~m})$

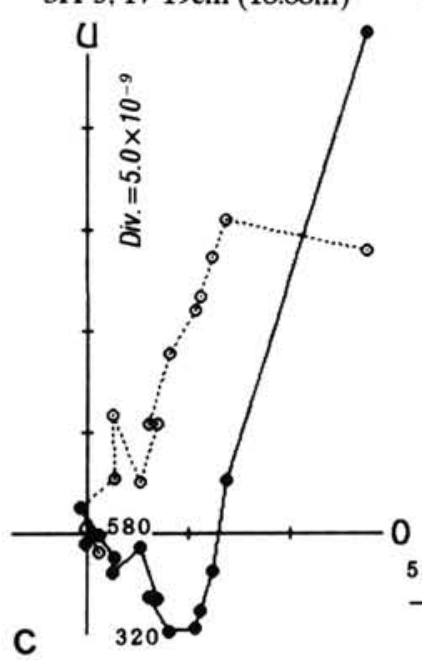

$3 \mathrm{H}-5.96-98 \mathrm{~cm}(19.67 \mathrm{~m}) \quad 3 \mathrm{H}-6.29-31 \mathrm{~cm}(20.50 \mathrm{~m})$
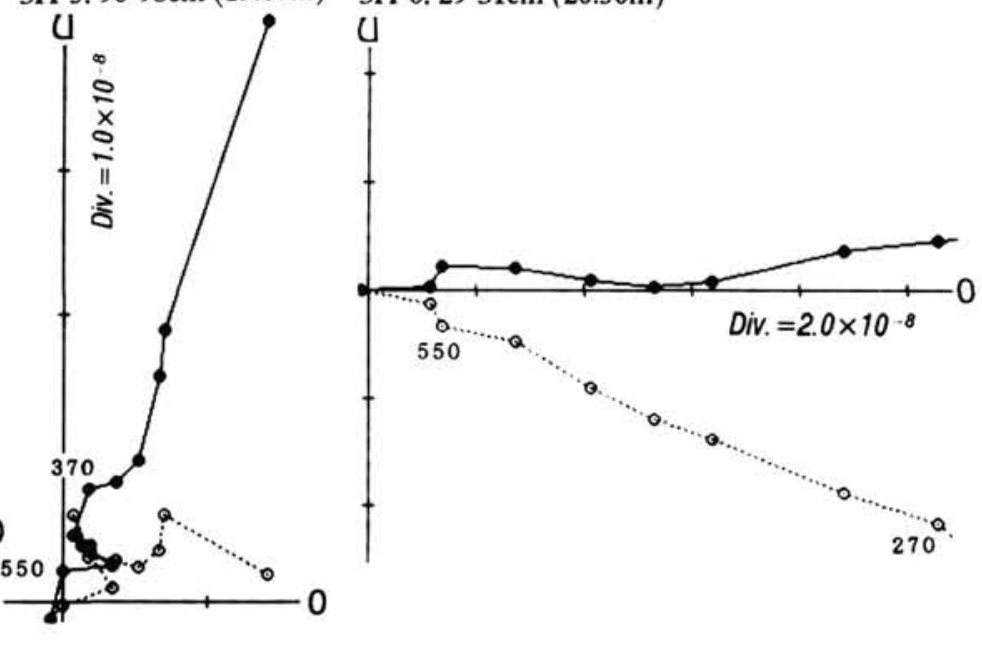

Figure 3 (continued). 

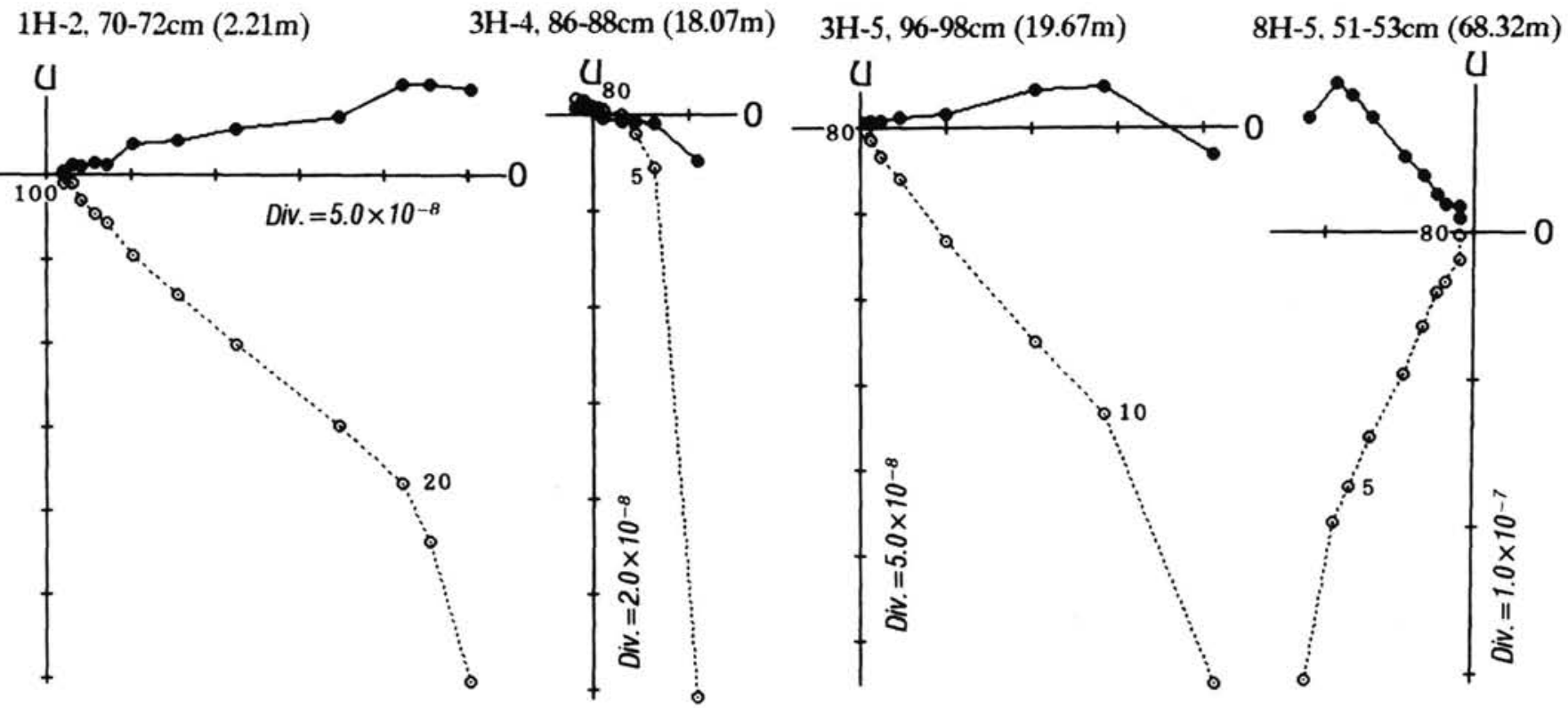

Figure 4. Examples of orthogonal projections of alternating field demagnetization data from Hole 650A. The peak field in mT is given for some of the points. Symbols as for Figure 3.

Donk, 1970) close to the base of $650 \mathrm{~A}-2 \mathrm{H}-3$, where the coiling change in Globorotalia truncatulinoides occurs (Fig. 9). The basal part of Core $2 \mathrm{H}$ is therefore supposed to correlate to Stage 2 . Core $3 \mathrm{H}$ is characterized by a "cold" assemblage correlative to Stage 2, and this is consistent with the Event 2.2 in the isotopic curve being close to the base of Core $3 \mathrm{H}$ (Vergnaud Grazzini et al., this volume). Foraminiferal assemblages correlative to Stage 3 occur toward the base of Core $4 \mathrm{H}$ and in Core $5 \mathrm{H}$. We conclude that "Event A" occurred within isotopic Stage 2, which has an age range of 12-24 ka (Martinson et al., 1987).

"Event B" occurs toward the base of Core $11 \mathrm{H}$. Glaçon (unpubl. data, reported in Channell, Rio, Sprovieri, and Glaçon, this volume) correlates Cores $10 \mathrm{H}, 11 \mathrm{H}$, and $12 \mathrm{H}$ to Stage 5 . As mentioned above, this is inconsistent with the interpretation of the oxygen isotope curve (Vergnaud Grazzini et al,. this volume) which correlated Core $9 \mathrm{H}$ to Stage 6 . In view of the low resolution of the isotopic curve in this interval, we weight the biostratigraphic data relative to the isotopic curve, and consider that Core $11 \mathrm{H}$ probably correlates to Stage 5. The age range of Stage 5 is estimated to be $73-100 \mathrm{ka}$ (Martinson et al., 1987).

\section{DISCUSSION}

There are numerous papers in the literature advocating geomagnetic "events" within the Brunhes Chron. Many of these proposals are based on spurious data subsequently attributed to the effects of current action and abrupt facies changes (Thompson and Berglund, 1976), with their publication prompted by the "snowballing action of the reinforcement syndrome" (Thompson and Oldfield, 1976, p. 176). With this in mind, and the fact that "events" of non-dipole origin would not be temporally correlative over large distances, it is noteworthy that the time intervals which bracket the "events" recorded at Hole $650 \mathrm{~A}$ coincide with the time intervals suggested for other proposed geomagnetic "events." For "Event A" there are several broadly synchronous "events" documented in the literature. The Mono Lake and Summer Lake excursions are both dated using tephrostratigraphy as being in the 24-29 k.y. interval (Liddicoat and Coe, 1979; Negrini et al., 1984). This is similar to the $27-30 \mathrm{ka}$ age range given by Barbetti and McElhinny (1976) for the Lake Mungo excursion. Negative inclinations recorded in Arctic Ocean cores by
Lovlie et al. (1986) were considered to correlate to oxygen isotopic Stages 2 and/or 3. It has been suggested that the Laschamp/Olby excursion (Bonhommet and Zahringer, 1969) is a self-reversal phenomenon (Heller and Peterson, 1982), and the age estimates of $35-44 \mathrm{ka}$ and $48 \pm 8 \mathrm{ka}$ given by Gillot et al. (1979) and Hall and York (1978), respectively, are distinctly different from the excursion ages mentioned above.

For "Event B," which appears to occur in isotopic Stage 5, there are several correlative "events" which are well documented. Tucholke et al. (1987) have recorded an "event" in several piston cores from the Tyrrhenian Sea and eastern Mediterranean, where it is correlated to oxygen isotopic substages $5 \mathrm{~d}$ and $5 \mathrm{e}$. This "event" may correlate to the Blake Event recorded in Atlantic and Caribbean cores (Smith and Foster, 1969; Denham, 1976; Denham et al., 1977), and to excursions of similar age from cores in southern Italy (Creer et al., 1980) and from Japan (Kawai et al., 1972; Nakajima and Miura, 1982). Age estimates for the Blake Event from Atlantic cores (100 k.y., Denham et al., 1977) are similar to those from volcanic ash in Japan (120 k.y., Nakajima and Miura, 1982) and from the southern Italian section, although the estimated duration of the event in Italy (up to 50 k.y.) (Creer et al., 1980) is ten times that estimated by Denham et al. (1977) and Tucholke et al. (1987) from deep-sea cores.

Although the regional manifestation and the short duration $\left(\sim 10^{3} \mathrm{yr}\right)$ of Brunhes geomagnetic events severely limits their usefulness as a means of stratigraphic correlation, their nature is critical to our understanding of the nature of the geomagnetic field itself. It is now clear that all proposed excursions within the Brunhes Chron are not aberrations of the data, and that the 20-30 ka and 100-140 ka intervals appear to feature geomagnetic events of several thousand years duration that are recorded over large areas. In view of the quality of the demagnetization data recording the "events" at Site 650 , we consider that a single component magnetization has been isolated. The samples were collected from the parts of the cores where compositional/color variations indicate lack of drilling related deformation. The slight bow-shape of visible compositional interfaces indicates almost no deformation in the intervals recording the "events" (see core photographs in Kastens, Mascle, et al., 1987, p. 177, 


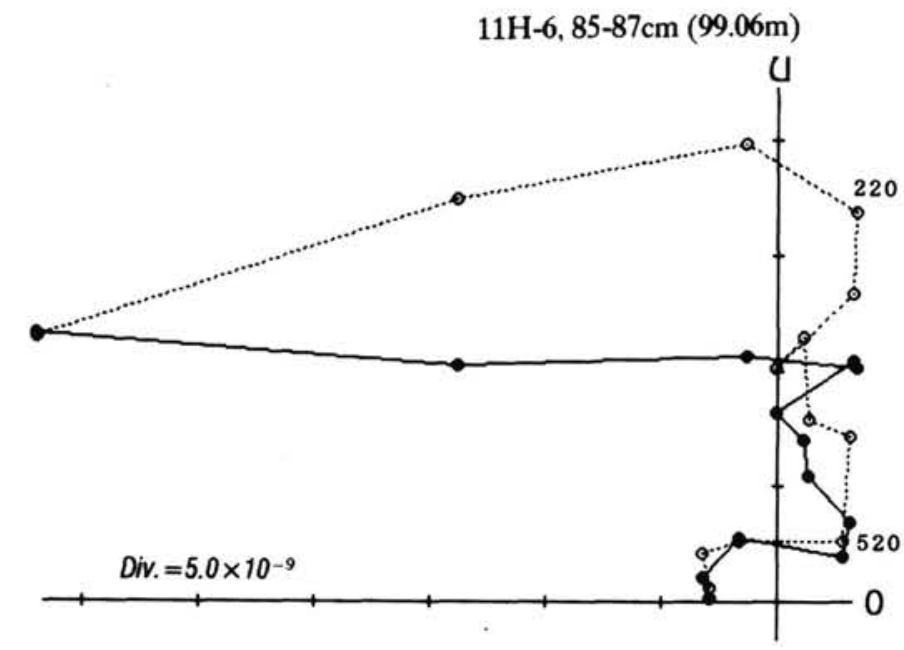

$11 \mathrm{H}-6,112-114 \mathrm{~cm}(99.33 \mathrm{~m})$
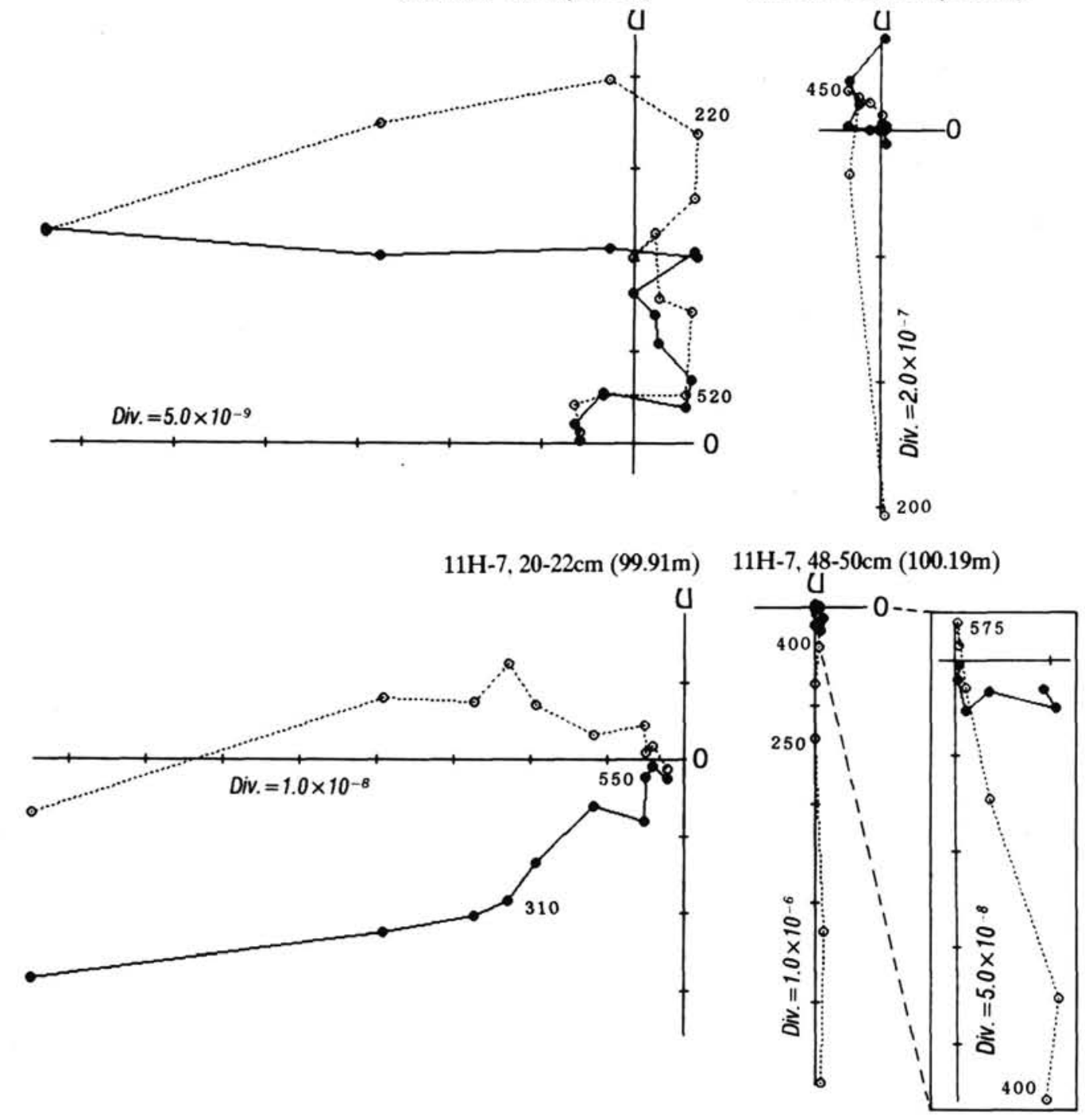

Figure 5. Orthogonal projection of thermal demagnetization data for samples recording "Event B" at Hole $650 \mathrm{~A}$. Symbols as for Figure 3.

193). In general, the declination values are more scattered than the inclination values, indicating the possibility of core rotation during drilling. However, in view of the generally pristine nature of the relevant cores, we consider that the observed inclination anomalies are not due to core deformation. Although the record of the Brunhes Chron at Hole 650A is very expanded compared to most marine records of this interval, the turbiditic lithology indicates reworking and variable sedimentation rates, which not only inhibit precise age control but also bring into question whether the "events" are an artifact of the depositional process. The samples recording the "events" were taken from very fine grained calcareous muds, which are not true hemipelagic sediments but appear to constitute the upper parts of distal turbidite flows. Sedimentation rates may have been very rapid in the intervals recording the "events." The lack of azimuthal orientation of the core at this site, and the general scatter in relative declination values limit the resolution of the dataset. Additional oriented piston cores from exceptionally thick records of the Brunhes Chronozone are necessary to confirm the nature of these "events."

\section{ACKNOWLEDGMENTS}

We wish to thank H. Tsurudome and T. Hawthorne for their help, particularly with the computer graphics, and F. McCoy for providing lithologic logs.

\section{REFERENCES}

Barbetti, M., and McElhinny, M., 1972. Evidence of a geomagnetic excursion 30,000 yr. B.P. Nature, 239:327-330.

Bonhommet, N., and Zahringer, J., 1969. Paleomagnetism and potassium argon age determinations of the Laschamp geomagnetic polarity event. Earth Planet. Sci. Lett., 6:43-46.

Broecker, W. S., and Van Donk, J., 1970. Insolation changes, ice volumes and the $\mathrm{O}^{18}$ record in deep-sea cores. Rev. Geophys. Space Phys., 8:169-198.

Creer, K. M., Readman, P. W., and Jacobs, A. ., 1980. Paleomagnetic and paleontological dating of a section at Gioia Tauro, Italy: identification of the Blake Event. Earth Planet. Sci. Lett., 50:289-300.

Denham, C. R., 1976. Blake polarity episode in two cores from the Greater Antilles outer ridge. Earth Planet. Sci. Lett., 29:422-434.

Denham, C. R., Anderson, R. F., and Bacon, M. P., 1977. Paleomagnetism and radiochemical age estimates for Late Brunhes polarity episodes. Earth Planet. Sci. Lett., 35:384-397. 
Gillot, P. Y., Labeyrie, J., Laj, C., Valladas, G., Guerin, G., Poupeau, G., and Delibrias, G., 1979. Age of the Laschamp paleomagnetic excursion revisited. Earth Planet. Sci. Lett., 42:444-450.

Hall, C. M., and York, D., 1978. K-Ar and 40Ar/39Ar dating of the Laschamp geomagnetic polarity reversal. Nature, 274:462-464.

Heller, F., and Peterson, N., 1982. Self-reversal explanation for the Laschamp geomagnetic polarity reversal. Phys. Earth Planet. Int., 30: 358-372.

Kastens, K. A., Mascle, J., et al., 1987. Proc. ODP, Init. Repts., 107: College Station, TX (Ocean Drilling Program).

Kawai, M., Yaskawa, K., Nakajima, T., Torii, M., and Horie, S., 1972. Oscillating geomagnetic field with a recurring reversal recovered from Lake Biwa. Proc. Japan Acad., 48: 186-190.

Kirschvink, J. L., 1980. The least squares line and plane and the analysis of paleomagnetic data. Geophys. J. Roy. Astr. Soc., 62:699-718.

Liddicoat, J. C., and Coe, R. S., 1979. Mono Lake geomagnetic excursion. J. Geophys. Res., 84:261-271.

Lovlie, R., Markussen, B., Sejrup, H. P., and Theide, J., 1986. Magnetostratigraphy in three Arctic Ocean sediment cores; arguments for geomagnetic excursions within oxygen-isotope stage 2-3. Phys. Earth Planet. Int., 43:173-184.

Martinson, D. G., Pisias, N. G., Hays, J. D., Imbrie, J., Moore, T. C., Jr., and Shackleton, N. J., 1987. Age dating and the orbital theory of the ice ages: development of a high resolution 0 to 300,000 years chronostratigraphy. Quaternary Res., 27:1-29.
Nakajima, T., and Miura, S., 1982. Blake polarity event found in the Hamaji Volcanic Ash Layer in Fukui Prefecture. Quaternary Research (Japan), 22:97-101.

Negrini, R. M., Davis, J. O., and Verosub, K. L., 1984. Mono Lake geomagnetic excursion found at Summer Lake, Oregon. Geology, 12:643-646.

Smith, J. D., and Foster, J. H., 1969. Geomagnetic reversal in Brunhes normal polarity epoch. Science, 163:565-567.

Thompson, R., and Berglund, B., 1976. Late Weichselian geomagnetic "reversal" as a possible example of the reinforcement syndrome. Nature, 263:490-491.

Thompson, R., and Oldfield, F., 1986. Environmental Magnetism: London (Allen and Unwin).

Tucholke, P., Fontugue, M., Guichard, F., and Paterne, M., 1987. The Blake polarity episode in cores from the Mediterranean Sea. Earth Planet. Sci. Lett., 86:320-326.

Yaskawa, K., Nakajima, T., Kawai, N., Torii, M., Natsuhara, N., and Horie, S., 1973. Palaeomagnetism of a core from Lake Biwa. $J$. Geomagnet. Geoelect., 25:447-474.

Date of initial receipt: 5 July 1988

Date of acceptance: 27 January 1989

Ms 107B-197 


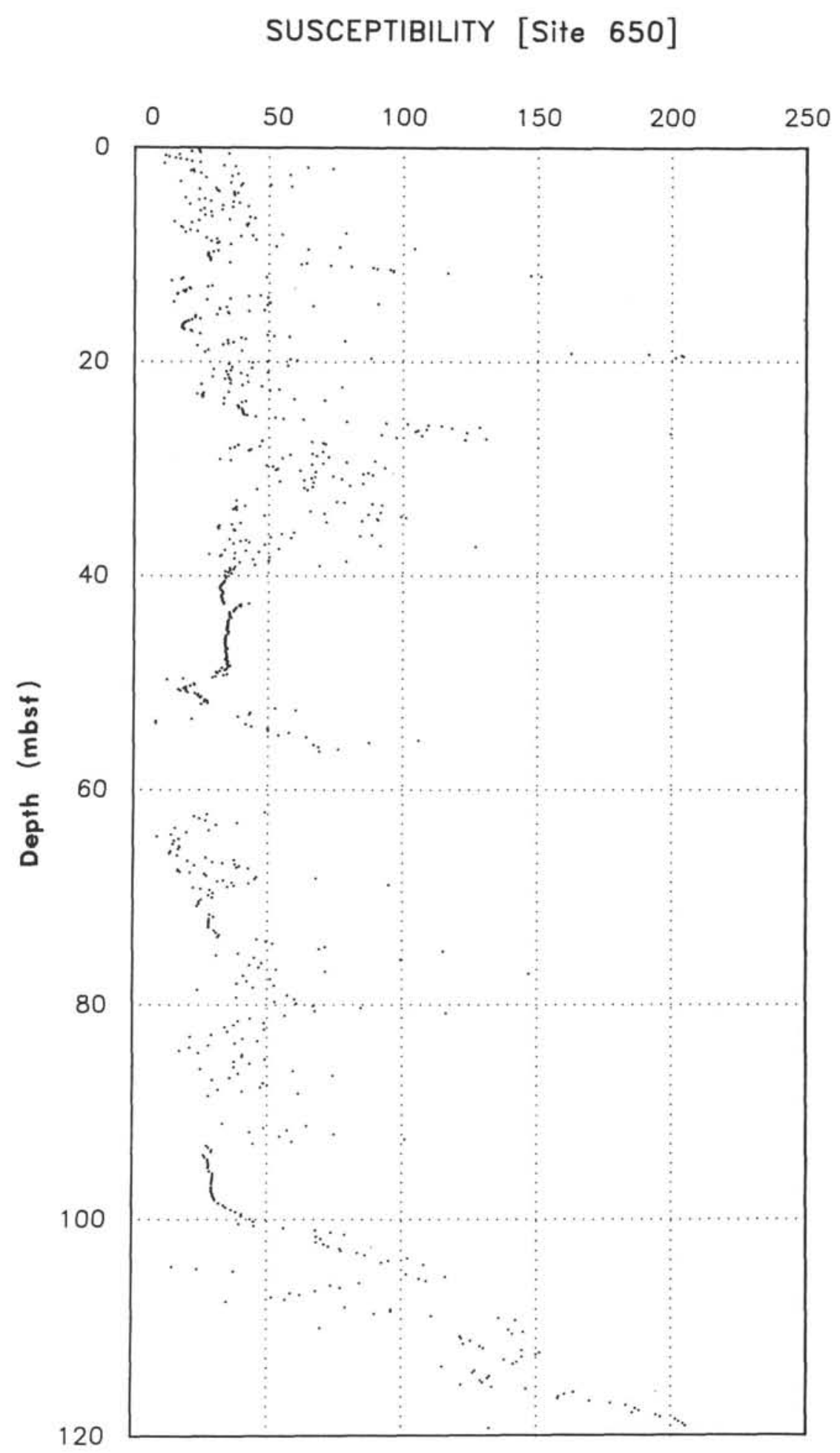

Figure 6. Magnetic susceptibility plotted against sub-bottom depth for the upper $120 \mathrm{mbsf}$ at Hole 650A. 


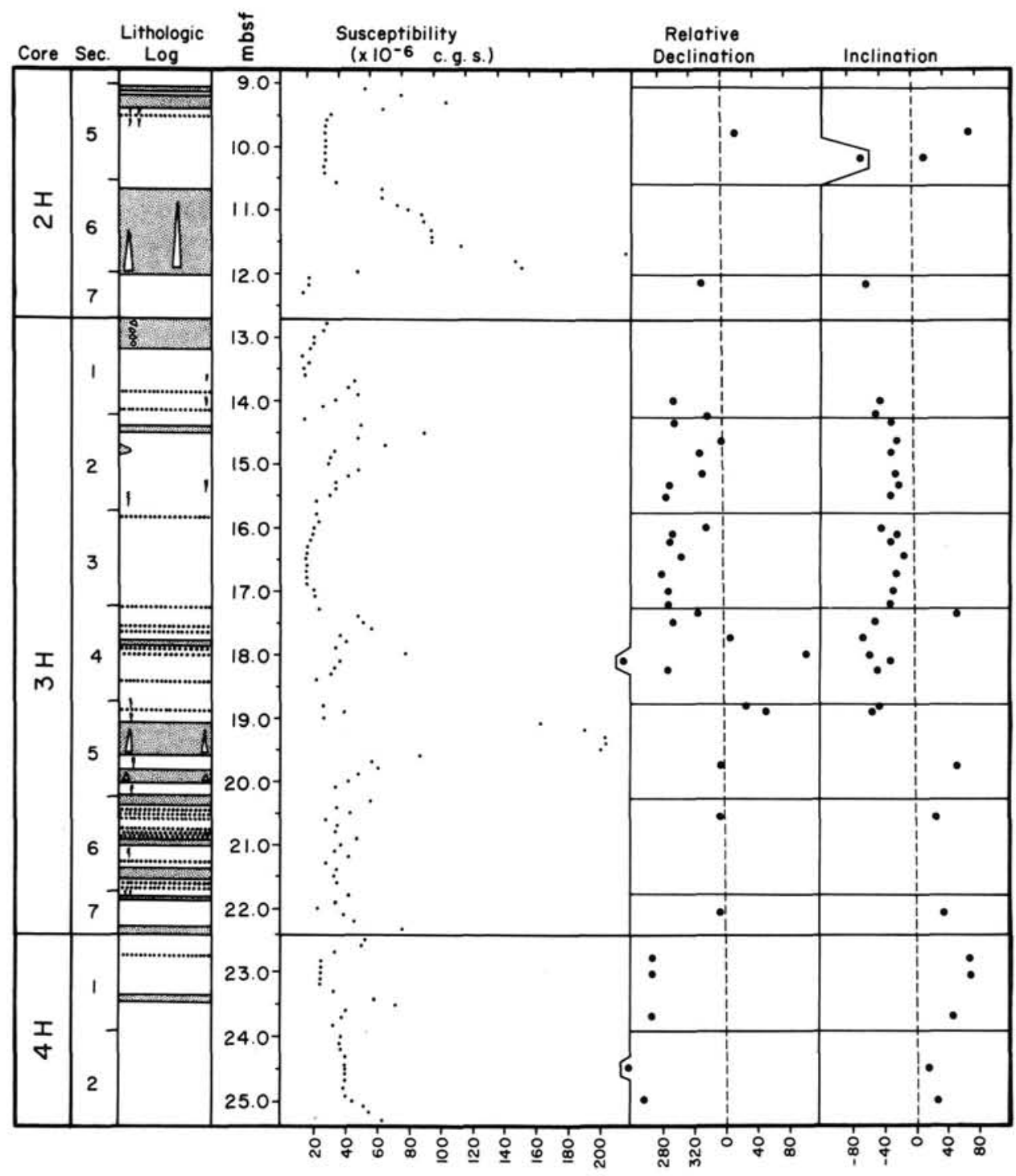

Figure 7. Lithologic log, magnetic susceptibility, and the well-defined remanence component direction for the interval at Hole 650A which records "Event A." Standard ODP symbols are used in the lithologic log. Core section breaks are indicated on the declination and inclination plots. Note that the coarser grained layers correspond to highs in the susceptibility values, and that these layers were generally avoided during sampling for magnetic remanence measurement. 


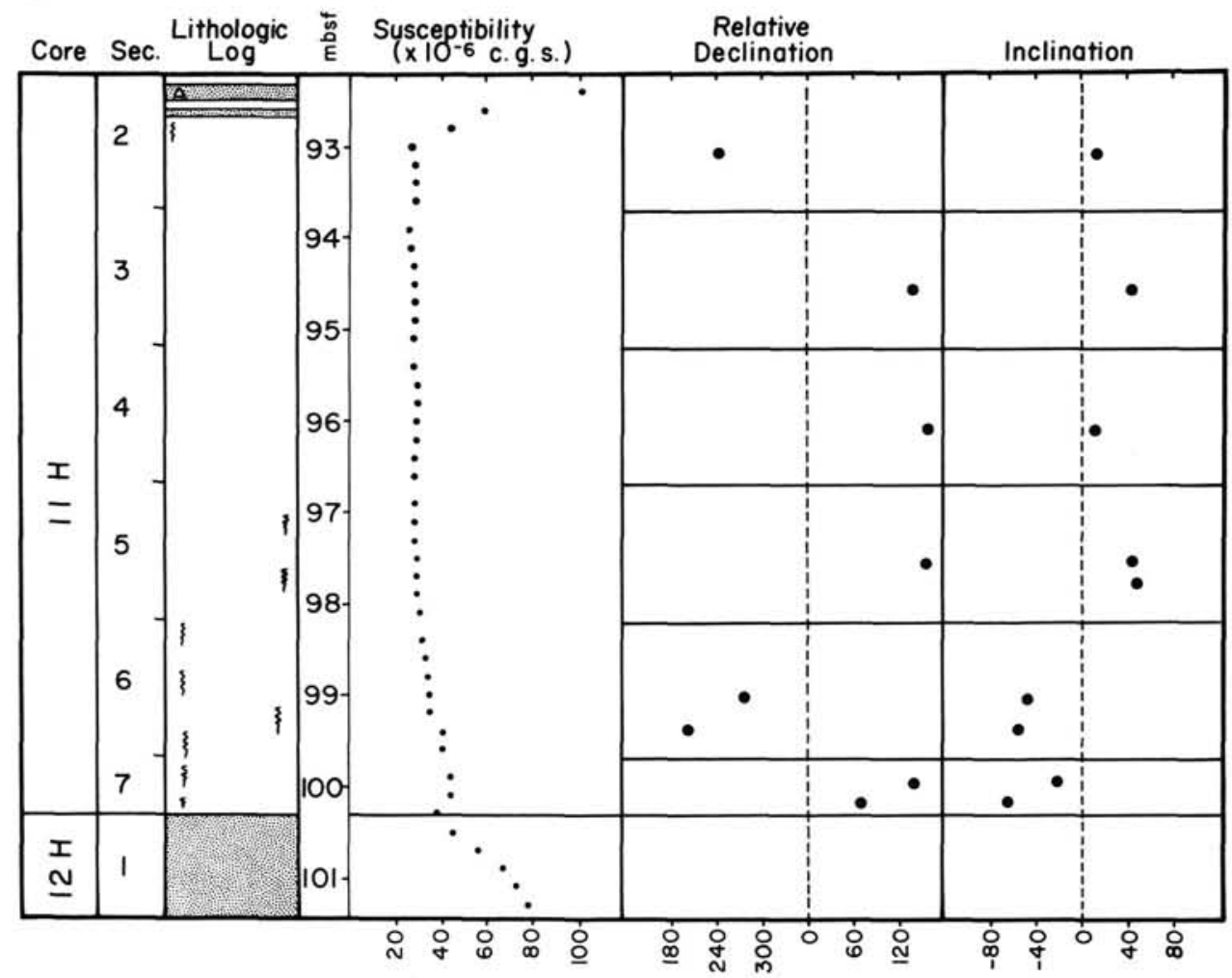

Figure 8. Lithologic log, magnetic susceptibility, and the well-defined remanence component directions for the interval at Hole 650A which records "Event B." Symbols as for Figure 7. "Event B" is recorded by four samples with negative inclinations at the base of Core $11 \mathrm{H}$. Due to the coarse grain size of the sediment in Cores $12 \mathrm{H}$ to $14 \mathrm{H}$, no samples were collected from these cores. 


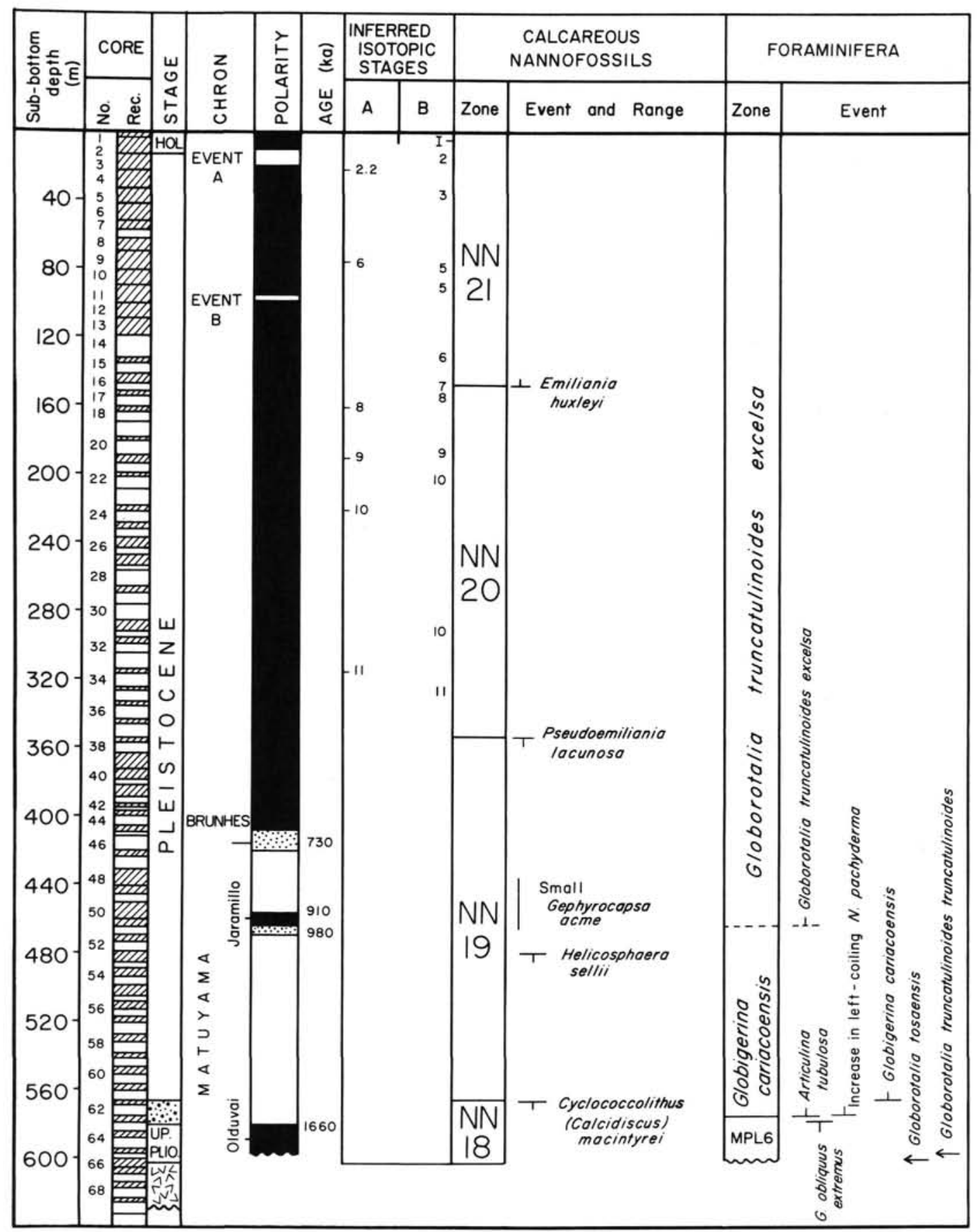

Figure 9. Chronostratigraphic data from Hole 650A (from Channell, Rio, Sprovieri, and Glaçon, this volume). Oxygen isotope stages in Column A are interpreted from the isotope curve by Vergnaud Grazzini et al. (this volume), and those in Column B are interpretations from the presence of "cold" and "warm" foraminiferal assemblages (Glaçon, unpubl. data). The nannofossil data are from Müller (this volume) and the foraminiferal data are from Glaçon et al. (this volume). 